\title{
Weronika Grozdew-Kołacińska
}

wgrozdew@wp.pl

Instytut Sztuki

Polska Akademia Nauk

\section{Muzyka tradycyjna i folkowa w Polsce - dialog międzykulturowy vs. hermetyzacja swojskości}

\author{
Traditional and Folk Music in Poland \\ - Intercultural Dialogue vs. Encapsulation of Homeliness
}

\begin{abstract}
Streszczenie: Autorka podnosi problem skrajnych postaw społeczno-kulturowych obserwowanych w środowiskach miejskich związanych z muzyką tradycyjną i folkową w Polsce. Ukazuje je w kontekście dwóch kategorii: „swojskości” i „międzykulturowości”. Wskazuje na przejawy hermetyzacji pewnych wartości uniwersalnych, płynących z muzycznego dziedzictwa kulturowego, jak również na ideologizację oraz instrumentalne ich traktowanie. Porusza także problem powierzchowności wiedzy w zakresie źródeł tradycji muzycznych (rodzimych i obcych), stanowiących inspiracje i podstawy działalności artystycznej. Autor również przykłady „dobrych praktyk” w zakresie międzykulturowego dialogu w sferze muzyki tradycyjnej i nią inspirowanej.
\end{abstract}

Słowa kluczowe: międzykulturowość, swojskość, muzyka tradycyjna, muzyka folkowa, dialog międzykulturowy

\begin{abstract}
Summary: The author discusses the issue of extreme socuio-cultural attitudes observable in the city milieus associated with traditional and folk music in Poland. He presents them in the context of two categories: those of "homeliness" and "multiculturalism", pointing to the signs of a hermetic stance towards some universal values derived from the musical heritage, as well as to the ideologization of those values and an instrumental approach to them. He also discusses the problem of the superficial nature of the knowledge concerning the sources of both native and foreign musical traditions that constitute the inspiration and the basis for artistic practices. He also gives examples of "good practice" in the area of intercultural dialogue in the areas of traditional music and music inspired by it.
\end{abstract}

Key words: multiculturalism, homeliness, traditional music, folk music, multicultural dialogue

Translated by Klaudyna Michałowicz

Muzyka tradycyjna i muzyka folkowa, mające duży wpływ na kształtowanie tożsamości, to dziś silne identyfikatory kultury w Polsce (Grozdew-Kołacińska 2014a, 2014b, 2016a). Obecność ich zaznacza się wyraźnie w przestrzeni społecznej (wciąż bardziej miast niż wsi) oraz w mass mediach. Coraz pewniej muzyka tradycyjna i muzyka folkowa wkraczają na sale koncertowe zarezerwowane dotąd dla tzw. sztuki wysokiej. Podobnie jak inne sztuki, oddziałują na emocje i zmysły, a dodatkowo odczuwane jako dziedzictwo pokoleń, 
które trzeba chronić (najskuteczniej poprzez praktykę), łatwo wywołują postawy skrajne, ulegają ideologiom i mogą służyć szeroko rozumianej manipulacji. Zarówno w środowiskach odwołujących się do dawnych muzycznych tradycji - przede wszystkich wiejskich, jak też tych, dla których muzyka tradycyjna stanowi inspirację w artystycznej twórczości (folk, World Music) - zauważyć można nasilające się tendencje do traktowania samej muzyki oraz kontekstów jej uprawiania, jako elementów przyjętych w danym środowisku ideologii lub postaw, odczuwanych i promowanych na zewnątrz, uznanych za wyłącznie słuszne i jedynie prawdziwe'. Wobec tej rzeczywistości oraz w aspekcie opisywanych poniżej zjawisk muzycznych i okołomuzycznych, podjęłam próbę namysłu nad problemem związanym $\mathrm{z}$ - zawartymi w tytule - pojęciami dialogu międzykulturowego i hermetyzacji swojskości.

Pierwszą, nasuwającą się nieodparcie refleksją było dostrzeżenie faktu, iż jedno z pojęć, zanim zdołało przekuć się w tzw. dobrą praktykę, zaczyna niechybnie tracić na aktualności, a przede wszystkim na wartości. Akcent zdecydowanie przesuwa się w stronę hermetyzacji, a „swojskość” jest pretekstem do okopania się i manifestowania jej w taki sposób, jak gdyby nie było pewności, czy jest ona na pewno „swoja” i jest na tyle prawdziwa, że nie zniszczy jej konfrontacja z „innością”. Tę „inność” dzieli czasem od „swojskości” duży dystans przestrzenny, ale zdarza się, że sąsiaduje z nią o przysłowiową „miedzę” albo przez - co dziś wymowne - ścianę. Dialog z ,innością”, pożądany przejaw myślenia międzykulturowego, może być więc rozpatrywany nie tyle w kategorii dystansu przestrzennego, co raczej mentalnego.

Od kilkunastu lat obserwuję rozwijający się wciąż w Polsce tzw. ruch folkowy, będąc równocześnie jego uczestnikiem. Opisuję go z perspektywy praktyka śpiewu tradycyjnego i członka muzycznych projektów folkowych oraz z perspektywy badacza-etnomuzykologa, a także (przez pewien czas) reprezentanta ministerialnej instytucji² ${ }^{2}$ której celem jest m.in. wspieranie i ochrona muzycznych tradycji w Polsce. Na fali ruchu folkowego, będącego echem zachodnioeuropejskiego music revival lat sześćdziesiątych XX wieku, przed ponad dwudziestu laty rozpoczął się w Polsce proces przywracania wartości autotelicznej muzycznemu dziedzictwu wsi (zjawisko to dotyczy przede wszystkim Polski nizinnej). Istotne jest przy tym, że chodzi tu o przywracanie wartości i doświadczenie muzyki odczuwane spontanicznie, a nie w postaci ugruntowanych praktyk zinstytucjonalizowanych, np. w ramach Koła Gospodyń Wiejskich, zespołów ludowych czy

\footnotetext{
${ }^{1} \mathrm{Na}$ ten fakt zwracano uwagę wcześniej, przede wszystkim jednak w kontekście wzajemnych relacji pomiędzy środowiskiem zwanym wówczas „purystycznym” a środowiskiem „folkowym” (zob. m.in. Wróbel 2001: 31, 35-36; Rokosz 2009: 83).

${ }^{2}$ W latach 2015-2017 sprawowałam funkcję koordynatora Pracowni Muzyki Tradycyjnej Instytutu Muzyki i Tańca.
} 
folklorystycznych (nie umniejszając w żaden sposób roli tych zjawisk w kulturze, zwłaszcza lokalnej).

Z początkiem lat dziewięćdziesiątych ubiegłego wieku powstały w Polsce środowiska, które świadomie zwróciły się ku ożywianiu i rekonstruowaniu dawnych muzycznych praktyk polskiej wsi. Były to grupy: Muzyka Kresów Jana Bernada i Moniki Mamińskiej oraz Bractwo Ubogich - nazywane później środowiskiem ,purystycznym” (Wróbel 2001: 31, 35-37; Rokosz 2009: 83, 213, 215), z którego powstały zespoły i projekty muzyczne Joanny Słowińskiej, Jacka Hałasa, Remka Hanaja, Janusza Prusinowskiego, Witolda Brody, Adama Struga i innych. Wcześniej, bo już w latach osiemdziesiątych XX wieku, działały grupy muzyczne, dla których muzyka tradycyjna (poznawana także często w warunkach jej naturalnego kontekstu, czyli na wsi i od wiejskich muzykantów) była inspiracją, a uczenie się jej nie stanowiło celu samego w sobie. Były to zespoły: Syrbacy, Kwartet Jorgi, później dołączyły do nich: Zespół Polski, Orkiestra św. Mikołaja, Kapela ze Wsi Warszawa i inne. Te dwa nurty muzyczno-społeczne od początku biegły równolegle i „pracowały” na dowartościowanie polskiej muzyki ludowej, wówczas określanej najczęściej muzyką korzeni, a dziś - muzyką tradycyjną. Z czasem postawy tych dwóch środowisk, zarówno wobec muzyki źródeł, jak i względem siebie zaczęły silnie się polaryzować, prowadząc niejednokrotnie do wzajemnych bardzo wyraźnych antagonizmów (Rokosz 2011: 119). W miarę jednak ugruntowywania się pozycji i popularności muzyki wiejskiej granej przez „muzykantów z miasta”, a także profesjonalizowania się muzyki folkowej, rozdźwięk między nimi wydaje się znacznie mniejszy, choć nadal muzyka tradycyjna i muzyka folkowa stanowią dwa światy, z rzadka tylko się zazębiające. Chodzi jednak przede wszystkim o wymiar ludzki i artykułowane ideologie, które nie zawsze przekładają się na kontekst muzyczny, bo ten wydaje się dziś dość mocno przeniknięty obydwoma nurtami. Świadczą o tym chociażby prezentacje na Festiwalu Polskiego Radia „Nowa Tradycja”, projekty muzyków in crudo w duchu, czy o znamionach muzyki sensu stricto folkowej lub wręcz avant-folkowej ${ }^{3}$ (m.in. Lautari, Ania Broda, Niewte, Adam Strug, Janusz Prusinowski Trio, Księżyc) $)^{4}$.

\section{Swojskość i wielokulturowość}

W dużym uproszczeniu można rzec, że środowisko związane z muzyką tradycyjną zwrócone jest głównie ku temu co „swoje” (lokalne, regionalne, narodowe), środowisko folkowe zaś, już u swego zarania, czerpie z tego co „obce” (muzyka grup mniejszościowych

\footnotetext{
${ }^{3}$ Określenie stosowane przez Remigiusza Mazura-Hanaja w kontekście zespołów, których działalność artystyczna, często na granicy eksperymentu, nie mieści się w przyjętych definicjach muzyki folkowej w Polsce.

${ }^{4}$ Przytoczona sytuacja różni się zatem diametralnie od tej, którą przywołuje Tomasz Rokosz (2011: 119).
} 
zamieszkujących Polskę i muzyka innych narodów - irlandzka, peruwiańska, indyjska, ukraińska, bałkańska - głównie cygańska itd.). W środowiskach tych pojawiają się czasem postawy skrajne - w przypadku pierwszym zamykanie się i izolowanie w „swojskości”, w drugim bezrefleksyjna pseudo-otwartość na to, co obce, egzotyczne. Ograniczenie się do tak prosto zarysowanego podziału i ukazanie tylko postaw skrajnych byłoby jednak krzywdzącym nadużyciem. Zarysuję zatem te postawy, które wydają się budzić pewien niepokój czy wątpliwości poznawcze i etyczne, a następnie wykażę (w obrębie tych samych środowisk) postawy, które - mówiąc językiem przytoczonych konwencji - stanowią przykłady „dobrych praktyk” i mają znaczenie dla przekazu i nabywania kompetencji kulturowych w ramach tradycji lokalnych, jak też mogą służyć budowaniu pomostów międzykulturowych w mocno dziś zantagonizowanym świecie.

Przejawy hermetyzacji swojskości, które cechują niektórych reprezentantów środowiska muzyki tradycyjnej uprawianej w tzw. wersji in crudo, skupionych obecnie głównie wokół nieformalnego stowarzyszenia Forum Muzyki Tradycyjnej ${ }^{5}$, sprowadzają się najczęściej do następujących postaw i działań:

- budowanie grup (wspólnot) na bazie własnego wyobrażenia o przeszłości, przyjętego w tej wspólnocie obrazu muzyki tradycyjnej, w oparciu o doświadczenie jej leaderów i określony język muzyczny. Grupy te tworzone są przez osoby wywodzące się z różnych tradycji, teraz połączone doświadczeniem, działaniem i uznawaniem jednego mistrza lub też tworzą nowy typ wspólnoty otwartej (Grozdew-Kołacińska 2016) - bez wspólnego korzenia, ale o „wspólnym doświadczeniu przez muzykę" ;

- monopolizowanie w obrębie własnej grupy (wspólnoty) wiedzy na temat muzyki tradycyjnej i jej wykonawstwa, przy jednoczesnym deprecjonowaniu dokonań wcześniejszych badaczy (zwłaszcza akademickich), co łączy się z postawą określaną jako „bycie pierwszym i jedynym znawcą tematu”;

- widzenie kultury muzycznej fragmentarycznie, np. przez pryzmat jednego regionu, jednego mistrza, czy też jednego gatunku muzycznego (w kontekście wyłącznie ,tu i teraz”), co jest przyczyną utrwalania niepełnego, a zdarza się, że i błędnego obrazu muzycznej tradycji - swojskość rozumiana jest wąsko, jako indywidualne, jednostkowe doświadczenie;

- postrzeganie innych tradycji muzycznych poprzez „swoją” (lub „oswojoną”) tradycję, negowanie ich wartości ze względu na cechy niepasujące do „właściwego” obrazu (będącego faktycznie wyobrażeniem) - np. muzyka reprezentowana przez

\footnotetext{
${ }^{5} \mathrm{~W}$ planach jest sformalizowanie stowarzyszenia i utworzenie federacji współpracującej z Pracownią Muzyki Tradycyjnej IMIT, koordynowanej od stycznia 2018 r. przez Piotra Piszczatowskiego.

${ }^{6}$ Z wypowiedzi Marty Domachowskiej (Domachowska 2014: 314).
} 
współczesne kapele kaszubskie nie jest uznawana w środowiskach muzyki tradycyjnej za tradycyjną;

- kształtowanie wizji polskiej muzyki narodowej opartej na jednej (lub znów - wyobrażonej) tradycji ${ }^{8}$ lub jednego stylu wykonawczego - co w konsekwencji przekłada się na promocję jednego regionu (czy mikroregionu) kosztem innych, równie ciekawych;

- wąskie pojmowanie ,polskości” muzyki, np. odmawianie jej zespołom folkowym, które muzykę polską grają ,po chińsku"”;

- monopolizowanie języka muzycznego i stylów wykonawczych (przekonanie o ,nawracaniu folkowców”, którzy uczestniczą w warsztatach muzyki tradycyjnej prowadzonych przez ,muzykantów miejskich” z nurtu in crudo).

Zauważyć można także takie przejawy hermetyzacji swojskości, która cechuje przedstawicieli obydwu środowisk. Jaskrawym przykładem jest tworzenie wokół muzyki ideologii:

- o „czystości” stylu, najwyższej wartości wykonywanej przez siebie muzyki (przede wszystkim jej subiektywnie pojmowanej ,„polskości”10), szukanie wspólnego języka z innymi kulturami poprzez odnajdywanie w nich ,polskich śladów"11;

- związanej ze światopoglądem politycznym lub religijnym (np. w repertuarze jednostronne ukazywanie wydarzeń historyczno-społecznych - pieśni o ,złych panach i dobrych chłopach") ${ }^{12}$. Promowane są spotkania śpiewacze, warsztaty dedykowane tradycyjnemu śpiewowi religijnemu (,nabożnemu”), nawiązującemu do założeń sprzed Vaticanum II, uznawanych przez tzw. tradycjonalistów za jedynie właściwe w śpiewie i liturgii Kościoła katolickiego;

- tworzenie wspólnot w ramach podobnych upodobań estetycznych i ideologicznych (w środowisku tradycjonalistycznym bliższy jest Węgier, Ukrainiec czy Serb grający muzykę tradycyjną, niż Polak grający muzykę folk lub folklor opracowany, stylizowany; i analogicznie - w środowisku folkowym, każda muzyka jest piękna, tylko nie ta wykonywana przez ,tradycjonalistę”).

\footnotetext{
${ }^{7}$ Z podobnym traktowaniem muzyka kaszubska spotyka się od wielu lat na konkursie podczas Ogólnopolskiego Festiwalu Kapel i Śpiewaków Ludowych w Kazimierzu Dolnym.

${ }^{8} \mathrm{Na}$ gruncie polskiej muzyki ludowej de facto zjawisko takie nie istnieje, polski idiom „,narodowy” to suma różnych tradycji regionalnych (por. Dahlig-[Turek] 2001; Nowak 2017).

${ }^{9}$ Z wypowiedzi Janusza Prusinowskiego (Domachowska 2014: 334).

${ }^{10}$ Stwierdzenie kategoryczne, iż ,polska muzyka jest najpiękniejsza na świecie” jest częstym motywem w wypowiedziach Adama Struga (Strug 2017: 93).

${ }^{11}$ Istotą tej postawy jest brak zainteresowania całokształtem danej kultury muzycznej i widzenie jej przez pryzmat polskich importów kulturowych.

${ }^{12}$ Przykładem może być tu projekt muzyczny „Ruta” Macieja Szajkowskiego.
} 
Nie trudno jednak zauważyć, że podstawy owych ideologii są często dość kruche - przestają mieć rację bytu, gdy w grę wchodzą pobudki merkantylne, czy też walka o odbiorcę w trakcie rozwijającej się kariery artystycznej.

Pojęcie wielokulturowości nie jest - jak wiadomo - równoznaczne z pojęciem międzykulturowości. Słowo to jest niejednokrotnie wytrychem w dyskursie potocznym, nadużywane zwłaszcza w reklamie wydarzeń kulturalnych i promowaniu regionów (,wielokulturowe Podlasie”, „wielokulturowy Wrocław” itp.), a także - sprowadzone do kolokwialnego „multikulti” - używane, zwłaszcza przez polityków, w sensie pejoratywnym. Taką wielokulturowość widać wyraźnie np. podczas festiwali folklorystycznych, w których „spotkanie kultur” przybiera głównie formę promocji i rywalizacji wielu różnych monologów „swojskości”. Rywalizacja wpisana jest - co oczywiste - w muzyczną tradycję, ale źle pojmowany, czy nierozważnie użyty termin „,wielokulturowość” może nieść ze sobą ryzyko wzmacniania poczucia odrębności, izolacji i konfliktów, zwłaszcza na terenach pogranicza.

W twórczości polskich zespołów folkowych dość powszechnym problemem jest brak wiedzy na temat pochodzenia muzyki, którą wykonawcy się inspirują (także swojej własnej, polskiej) i posługiwanie się treściami muzycznymi, których jedynym źródłem poznania staje się internetowy kanał You Tube lub twórczość innych zespołów folkowych, a także popularne „warsztaty śpiewu białego”. Konsekwencją tego bywa niejednokrotnie zjawisko plagiatu muzycznego - podlegają mu zarówno aranżacje i opracowania oryginalnych melodii ludowych, jak i melodie autorskie inspirowane muzyką tradycyjną, błędnie uznawane za „ludowy autentyk”. Ze względu na powierzchowność „łowienia” materiału muzycznego do opracowania, zwiększa się też powtarzalność repertuaru tradycyjnego w wykonaniach zespołów folkowych. Ten ostatni problem dotyczy również niektórych „muzykantów z miasta”, których zasób repertuarowy ogranicza się z kolei do utworów poznawanych na warsztatach i taborach Domu Tańca.

Nieznajomość kultury muzycznej, z której czerpie się inspiracje, powoduje także utrwalanie błędnego obrazu całokształtu tej kultury - stąd też np. w naszym kraju „muzyka bałkańska" kojarzona jest przede wszystkim, a najczęściej wyłącznie, z dętymi orkiestrami cygańskimi ${ }^{13}$ oraz z kilkoma pieśniami, namiętnie odgrywanymi przez tzw. zespoły klezmerskie w Polsce - choć nie tylko, bo „przeboje” takie jak Jowano,

\footnotetext{
${ }^{13}$ Ma to również swoje podłoże w ogromnej w Polsce popularności projektów Gorana Bregovića, która pojawiła się po jego pierwszym występie na Malta Festival w Poznaniu w 1997 roku, kiedy zagrał wspólnie $\mathrm{z}$ „weselno-pogrzebową" dętą orkiestrą cygańską (oficjalna nazwa orkiestry - The Wedding and Funeral Band). Ta popularność, połączona z kinem lat dziewięćdziesiątych Emira Kusturicy sprawiła, że do Polski zaczęto zapraszać inne orkiestry cygańskie - Fanfare Ciocărlia, Boban i Marko Marković, Koćani Orkestar, Taraf de Haydouks, Mahala Rai Banda i in.
} 
Jowanke, Ajde, Jano czy Oj, dewojko, duszo moja zyskały dużą popularność także w zespołach folklorystycznych.

\section{Kultura dialogu i porozumienia}

Powyższe refleksje nie mają na celu stygmatyzowania żadnego ze środowisk oraz indywidualnych osób wspomnianych z nazwiska, ani nie deprecjonują ich działalności - artystycznej i społeczno-kulturowej. Służą jedynie ukazaniu pewnych postaw, które nie powinny być pomijane w humanistycznym namyśle i refleksji naukowej, zwłaszcza w dzisiejszym skomplikowanym świecie. Zasięg tych postaw nie ogranicza się zatem do przytoczonych powyżej przykładów jednostkowych, ale kształtuje rzeczywistość o wiele szerszą. Postawy te implikują zjawiska i przemiany w obszarze kultury muzycznej w ogóle. To, w jaki sposób muzyka uprawiana przez rekonstruktorów i kontynuatorów z miasta kształtuje wiejską kulturę lokalną, powinien dokumentować i objąc refleksją naukową współczesny etnomuzykolog. Działania środowisk i jednostek kształtują bowiem i wywołują konkretne ustalenia w sferze systemowej, instytucjonalnej. Muzyka i jej przekaz treściowy (werbalny i pozawerbalny) pełnią ważną funkcję edukacyjną i informacyjną (komunikuje) - ukazują nastroje społeczne, wyrażają światopogląd i tożsamość osób, środowisk, grup, narodów itd. Uświadamianie sobie istnienia różnorakich postaw wyrażanych poprzez muzykę (czy wręcz wykorzystujących ją), wydaje się ważne w obliczu nagłej i niezwykle szybko postępującej transformacji społecznej i kulturowej w Europie, a także wobec realnych zagrożeń ze strony - już nie budzących się, ale krzyczących nacjonalizmów i postaw ksenofobicznych, a także infantylizacji i spłycania wartości - także tych, które tkwią w kulturze tradycyjnej, np. obrzędowości religijnej (Grozdew-Kołacińska 2016a). Promocja jedynie słusznej wizji muzyki, ideologizacja przekazu, wykrzywianie obrazu innej kultury - to zabiegi znane z nieodległej przeszłości. A przecież ruch folkowy i odkrywanie muzyki tradycyjnej „na nowo” wzięły się między innymi właśnie z kontestacji, z buntu przeciwko instrumentalnemu traktowaniu muzyki ludowej dla celów propagandowych i politycznych. Samo pojęcie muzyka ludowa, aby nie budzić skojarzeń z „ludową demokracją”, zostało zamienione na muzyka tradycyjna (Grozdew-Kołacińska 2014b: 40). Dlatego tak ważne jest podejmowanie dialogu - na poziomie międzyśrodowiskowym, międzyetnicznym, międzynarodowym, międzyreligijnym, czyli międzyludzkim. Międzykulturowość nie ogranicza swojskości, przeciwnie - pozwala jej wybrzmieć. Wspomniane wcześniej kompetencje kulturowe, na gruncie swojskości powinny iść w parze z przekazem kompetencji międzykulturowych, szczególnie na obszarach pogranicznych czy terenach o wymieszanej ludności. 
Aby móc docenić czyjąś muzykę, trzeba ją poznać (tak jak język), aby móc z kimś muzykować, trzeba tę muzykę poznać jeszcze lepiej, żeby współbrzmienie było zgodne i wzajemnie się uzupełniało, by można było prowadzić dialog - czyli dawać równoważną przestrzeń dla każdej wypowiedzi, wzajemnie się słuchać i rozumieć. W dialogu nie ma miejsca na forsowanie swojego stanowiska. Tradycyjny wykonawca z Podlasia ma prawo śpiewać na kazimierskim festiwalu „po swojomu”, nie musi śpiewać po polsku. Nie musi również przebierać się w jeden z białoruskich strojów ludowych (przywiezionych z magazynów z Mińska) na przeglądzie regionalnym.

Nabywanie kompetencji kulturowych należałoby również odnieść do uprawiania własnej (swojskiej) kultury muzycznej. Artysta folkowy czy jazzowy ma prawo opracować i grać melodię ludową według własnej, artystycznej wizji, nie musi trzymać się kanonu wykonawczego wyznaczonego przez radomskiego skrzypka lub kurpiowskiego śpiewaka. Dobrze jednak, aby miał świadomość, że takie kanony istnieją, a ich zastosowanie w praktyce świadczyłoby o posiadanej wiedzy i nabyciu kompetencji. Jakiż szacunek do muzyki i „innego” musiał mieć słynny podhalański skrzypek Bartuś Obrochta (1815-1926), żeby przyznać Karolowi Szymanowskiemu (1882-1937): „Piknieście to wyzdajali, panie Szymanowski. Wy juz cosii takiego w uchu mocie, cosi inkse jako jo, ale tyz dobre!" (Chylińska 1976: 80).

Zarówno w środowisku muzyki tradycyjnej, jak i folkowej mają miejsce inicjatywy, które a priori zakładają międzykulturową współpracę, opartą na wzajemnym poznawaniu przedstawianych wartości i traktowaniu ich jako równorzędnych we wspólnym muzykowaniu (zarówno na gruncie rodzimym, jak i szerszym - międzynarodowym). Przykładem mogą tu być projekty muzyczne podhalańskiej rodziny Trebuniów-Tutków z jamajskim zespołem Twinkle Brothers, czy - najnowszy - z gruzińskim zespołem Urmuli. Także zespół Naxos Milo Kurtisa, projekt „Usłyszeć Taniec”, międzynarodowe projekty muzyczne Marii Pomianowskiej (m.in. Indie, Pakistan, Chiny, Korea, Iran, Afganistan, Senegal), a także niezwykle ciekawy projekt „Żywizna” Raphaela Rogińskiego z Genowefą Lenarcik są dowodem na to, że muzyka jest doskonałym łącznikiem między kulturami i etnosami. Istnieją też wspólne projekty artystów uznających siebie za kontynuatorów muzyki tradycyjnej z artystami folkowymi (np. Kapela Niwińskich z Magdaleną Sobczak-Kotnarowską, zespół Adama Struga z Wojciechem Lubertowiczem, Kapela Brodów z Martą Maślanką) ${ }^{14}$.

Podejmowana jest też w skali lokalnej niełatwa „praca u podstaw” w promowaniu międzykulturowego i międzypokoleniowego dialogu, np. działalność Fundacji Ważka

\footnotetext{
${ }^{14}$ Traci tu rację bytu teza o niemożności dialogu (Rokosz 2011: 119-120) pomiędzy muzykami folkowymi i „purystami” (określenie to zresztą niemal całkowicie się dziś zdezaktualizowało) - chodzi tu przede wszystkim o dialog na gruncie muzycznym.
} 
na Dolnym Śląsku, Filharmonii Szczecińskiej im. M. Karłowicza, Stowarzyszenia „Tratwa” czy Ani Brody na Warmii i Mazurach. Na gruncie współpracy międzynarodowej przykładem może być działalność Fundacji „Muzyka Kresów” z Lublina, Fundacji „Pogranicze” z Sejn, również organizowanie Festiwalu Folkowego „Z wiejskiego podwórza” w Czeremsze (Podlasie), Taboru Rodzinnego w Zawadce Rymanowskiej, festiwalu polsko-litewskiego „Wilno w Gdańsku”, festiwali World Music - Skrzyżowanie Kultur, Ethnoport, Globaltica, Pannonica, Rozstaje i wiele innych.

\footnotetext{
Miałem szczęście poznać innych ludzi poprzez muzykę. Wielki wpływ miał na mnie ojciec - śpiewał melodie, których korzenie tkwiły w starej chasydzkiej tradycji kulturowej. Pomógł mi również George Enescu, który wprowadził mnie w świat dźwięków z Węgier i Rumunii. Powinniśmy dzielić się naszą sztuką, naszymi krajobrazami, naszymi smutkami i radościami, powinniśmy poszerzać nasze horyzonty. W ten sposób prawdziwie zrozumiemy grupy ludzi, którzy cierpią z powodu prześladowań (Yehudi Menuhin) (Mazowieckie Obserwatorium...).
}

Ostatecznie, tak jak cała Europa, stajemy dziś przed wyzwaniem znalezienia modus vivendi z kulturami, które wydają się nam bardzo dalekie i obce. Pamięć narodu jest - jak się okazuje - krótka i wybiórcza. Rzeczpospolita Wielu Narodów w świadomości współczesnego przeciętnego obywatela nie istnieje, jest nie do wyobrażenia. Muzyka, jak pokazują przytoczone przykłady, zwłaszcza ta tradycyjna i nią inspirowana, przenoszona pieczołowicie w czasie i przestrzeni, stale uwspółcześniana, oswajana, traktowana nie tylko jako dziedzictwo, które trzeba chronić, ale przede wszystkim jako żywy sposób ekspresji najważniejszych uczuć i wartości - może być doskonałą formą i platformą porozumienia z ,innym”. Rolą zaś środowiska naukowego jest dziś - jak się wydaje - nie tylko obserwacja i dokumentacja zjawisk, ale także umiejętność stawiania diagnozy i inspirowanie do podejmowania działań formalnych i nieformalnych, lokalnych i globalnych, które służą już nie tylko zachowaniu tradycyjnych form przekazu, ale budowaniu na ich podstawie trwałych więzi międzyludzkich. Jest to dziś także jeden z najważniejszych postulatów europejskiej etnomuzykologii stosowanej (International Council for Traditional Music), odnoszący się zwłaszcza do tych regionów i tych społeczności, dla których świat stał się szczególnie nieprzychylny, które nie mogą zamknąć się w bezpiecznej „swojskości”, z którymi dialog jest być może trudny, ale wciąż jeszcze możliwy i pożądany.

Podsumowując refleksję na temat postaw zaobserwowanych w środowiskach związanych z muzyką folkową oraz muzyką tradycyjną, chciałabym wspomnieć o dwóch ważnych międzynarodowych dokumentach, które - ze względu na fakt, iż dotyczą w sposób bezpośredni uczestników i twórców kultury - powinny mieć, jak się wydaje, szeroki wpływ na kształtowanie świadomości społecznej. Pierwszy z nich to Konwencja 
UNESCO w sprawie ochrony i promowania różnorodności form wyrazu kulturowego z 2005 roku, ratyfikowana w Polsce w roku 2007. Stwierdza ona m.in., że „różnorodność kulturowa jest cechą właściwą ludzkości” i jest jej „wspólnym dziedzictwem” oraz uznaje jego ochronę jako „konkretny i etyczny imperatyw stanowiący nieodłączny element poszanowania ludzkiej godności”. Mówi ona również o „wspieraniu inicjatyw międzykulturowych, mających na celu pogłębianie interakcji kultur, w celu ułatwienia kontaktu pomiędzy społecznościami”. Uznanie różnorodności kulturowej jest ważnym uzupełnieniem praw człowieka.

Drugi ze wspomnianych dokumentów to Konwencja UNESCO w sprawie ochrony niematerialnego dziedzictwa kulturowego z 2003 roku, implementowana w Polsce w roku 2011, która od kilku lat żywo zajmuje liczną grupę polskich uczonych, animatorów kultury, artystów, urzędników państwowych oraz reprezentantów wspomnianych wyżej środowisk (zwłaszcza tych, związanych z muzyką tradycyjną in crudo). Czytamy w niej m.in., iż Konferencja Generalna Organizacji Narodów Zjednoczonych dla Wychowania, Nauki i Kultury przyjęła konwencję „mając na względzie znaczenie niematerialnego dziedzictwa kulturowego jako źródła różnorodności kulturowej i gwarancji zrównoważonego rozwoju” oraz „uznając, że procesy globalizacji i przemian społecznych, chociaż tworzą nowe warunki dla dialogu między wspólnotami, powodują, podobnie jak zjawisko nietolerancji, poważne zagrożenie w postaci degradacji, wyginięcia i zniszczenia niematerialnego dziedzictwa kulturowego", a także „uznając, że wspólnoty, w szczególności ludy autochtoniczne, grupy oraz, w niektórych przypadkach, pojedyncze osoby, odgrywają znaczącą rolę w tworzeniu, ochronie, utrzymywaniu oraz odtwarzaniu niematerialnego dziedzictwa kulturowego, przyczyniając się tym samym do wzbogacenia różnorodności kulturowej oraz ludzkiej kreatywności”. Co ciekawe - jako pierwszą ratyfikowano w Polsce Konwencję w sprawie ochrony i promowania różnorodności form wyrazu kulturowego. Nie ma ona jednak tak bezpośredniego przełożenia na działania w obrębie kultury tradycyjnej w Polsce, jak Konwencja w sprawie ochrony niematerialnego dziedzictwa kulturowego, której wpływ na działania w obszarze kultury tradycyjnej jest zdecydowanie zauważalny. W wyniku poruszenia wywołanego ratyfikacją tej ostatniej, rangi instytucjonalnej nabrały w dużym stopniu te aktywności, które wcześniej pozostawały w sferze indywidulanej troski jednostek oraz małych nieformalnych grup i stowarzyszeń, przede wszystkim związanych z ożywianiem dawnych tradycji na wsi. Utworzono programy ministerialne dedykowane specjalnie tym grupom i osobom, ukierunkowane na działania in situ, ale także na działania systemowe ogólnopolskie, subwencjonowane z budżetu państwa (Grozdew-Kołacińska 2016b). W przypadku drugiej z przytoczonych konwencji podobnego oddźwięku nie było. Z pewnością nie należy 
przeceniać bezpośredniego oddziaływania tego typu aktów - bądź co bądź urzędowych - na zjawiska kulturowe i kształtowanie postaw społecznych, które w dużym stopniu zdają się być wciąż samorzutne w muzycznych środowiskach. Jednak - poprzez zaangażowanie licznych reprezentantów środowisk w urzeczywistnianiu założeń tych dokumentów - wytyczają one pośrednio kierunki myślenia i podejmowanych inicjatyw w obrębie grup i społeczności. Być może, gdyby treści obydwu konwencji w równym stopniu zajmowały badaczy, animatorów, regionalistów, edukatorów, urzędników i inne osoby aktywne w obszarze muzycznej kultury tradycyjnej, czy też gdyby rzeczywiście były one traktowane jako uzupełniające się i ważne dokumenty z zaleceniami wartymi promowania w środowiskach, o których wyżej mowa, problem postępującej hermetyzacji swojskości byłyby zminimalizowany, a dialog międzykulturowy i poszanowanie inności stanowiłyby wartości tyleż uświadomione co pożądane.

\section{Bibliografia}

Chylińska, T. (1976). Zakopiańskie dni Karola Szymanowskiego. 1894-1936. Kraków: Polskie Wydawnictwo Muzyczne.

Dahlig-[Turek], E. (2001). Muzyka ludowa, muzyka narodowa. W: M. Janicka-Słysz, T. Malecka, K. Szwajgier (red.), Muzyka w kontekście kultury. Studia dedykowane Profesorowi Mieczysławowi Tomaszewskiemu w osiemdziesięciolecie urodzin (s. 589-598). Kraków: Akademia Muzyczna.

Domachowska, M. (2014) (oprac.). Głos Forum Muzyki Tradycyjnej w sprawie kultury tradycyjnej w Polsce. Zapis dyskusji środowiskowej. W: W. Grozdew-Kołacińska (red.), Raport o stanie tradycyjnej kultury muzycznej (312-334). Warszawa: Instytut Muzyki i Tańca.

Grozdew-Kołacińska, W. (2014a). Muzyka folkowa - „tradycja na skróty” czy „współczesna muzyka ludowa"? W: W. Grozdew-Kołacińska (red.), Raport o stanie tradycyjnej kultury muzycznej (48-53). Warszawa: Instytut Muzyki i Tańca.

Grozdew-Kołacińska, W. (2014b). Muzyka tradycyjna, śpiew tradycyjny, taniec tradycyjny, próba konfrontacji terminów z rzeczywistością zastaną. W: W. Grozdew-Kołacińska (red.), Raport o stanie tradycyjnej kultury muzycznej (40-47). Warszawa: Instytut Muzyki i Tańca.

Grozdew-Kołacińska, W. (2016a). „Do tańca i do różańca” - funkcje muzyki tradycyjnej dziś. Kultura Enter, nr 73. Pozyskano ze strony: http://kulturaenter.pl/article/ retradycja-do-tanca-i-do-rozanca-funkcje-muzyki-tradycyjnej-dzis/.

Grozdew-Kołacińska, W. (2016b). W stronę etnomuzykologii stosowanej - Pracownia Muzyki Tradycyjnej IMiT. Łódzkie Studia Etnograficzne, t. 55, s. 140-160. 
Nowak, T. (2016). Taniec narodowy w polskim kanonie kultury. Źródła, geneza, przemiany. Warszawa: Instytut Muzykologii Uniwersytetu Warszawskiego.

Rokosz, T. (2009). Od folkloru do folku. Metamorfozy pieśni tradycyjnych we współczesnej kulturze. Siedlce: Wydawnictwo Akademii Podlaskiej.

Rokosz, T. (2011). Radykalni rekonstruktorzy tradycji kontra wykonawcy folk. W: S. Szynkiewicz, B. Walęciuk-Dejneka, T. Rokosz (red.), Dialog i konfrontacja w tekstach kultury polskiej (s. 107-122). Siedlce: Wydawnictwo Uniwersytetu Przyrodniczo-Humanistycznego w Siedlcach.

Strug, A. (2017). Niezamierzony efekt komiczny. W: W. Grozdew-Kołacińska, B. Drozd (red.), Śpiew tradycyjny - modele edukacji. Doświadczenia serbskie i polskie (s. 91-93). Lublin: Warsztaty Kultury.

Wróbel, E. (2001). Folklor a muzyka środowisk młodzieżowych w Polsce lat dziewięćdziesiątych. Muzyka, nr 3, s. 27-38.

\section{Strony internetowe}

Mazowieckie Obserwatorium Kultury - http:/www.mazowieckieobserwatorium.pl/ media/_mik/files/261/201405-omc-diversity-dialoguepl.pdf 